\title{
Vulnerability to climate change in smallholder farming households: a case study of Eritrea
}

\author{
Debesai Ghebreselassie ${ }^{1,2, *}$, Vlad Makeev ${ }^{1}$, and Tatyana Kushnarenko ${ }^{1}$ \\ ${ }^{1}$ Don State Technical University, Gagarin sq., 1, Rostov on Don, 344003, Russia \\ ${ }^{2}$ Hamelmalo Agricultural College (HAC), Eritrea P.O. Box 397
}

\begin{abstract}
Climate change is adversely affecting smallholder farming households in Eritrea mainly due to the dependence their livelihood to the climate-regulated activity. This study examines the degree of vulnerability of smallholder farming households in Eritrea using a Vulnerability Livelihood Index (VLI). Major components of vulnerability to climate change were identified as Exposure, Sensitivity and Adaptive Capacity. More than $88 \%$ of the farming households were found to be vulnerable or highly vulnerable to climate change as a result of the combined effect of their exposure to external factors, sensitivity to internal factors, and lower adaptive capacity. Female-headed households and those belonging to disadvantaged low-income groups were more vulnerable and in need of being preferentially targeted by policy measures. Improving human resource development by focusing on education and health, and enhancing adaptive capacity by focusing on access to food and water can develop the resilience of the farming households.
\end{abstract}

\section{Introduction}

Definitions of vulnerability to environmental stress vary considerably. Vulnerability is conceptualized in a very different ways by scholars from different knowledge domains, and even within the same domain $[1,2]$. From a social science perspective, it is people who are vulnerable to climate change, and it is institutions, economies and societies which adapt and respond to present-day risks from climate variability and to future changes in climate [3]. The conventional use of the word "vulnerability" refers to the capacity to be wounded, or the degree to which a system is likely to experience harm due to exposure to a hazard [4]. Vulnerability is pervasive in all countries, but most destructive in developing countries specifically in Africa [1].

Africa is one of the most vulnerable continents to climate change, a situation aggravated by the interaction of 'multiple stresses', occurring at various levels, and low adaptive capacity [5]. Africa's major economic sectors are vulnerable to current climate sensitivity, with huge economic impacts, and this vulnerability is exacerbated by multitude factors including endemic poverty, complex governance and institutional dimensions; limited access to capital, including markets, infrastructure and technology; ecosystem degradation;

\footnotetext{
*Corresponding Author: robeljan20134@gmail.com
} 
and complex disasters and conflicts. These, in turn, have contributed to Africa's weak adaptive capacity, increasing the continent's vulnerability to projected climate change [2].

According to the projections of the Intergovernmental Panel on Climate Change [2], agricultural production, including access to food, in many African countries and regions is estimated to be severely compromised by climate variability and change. The area suitable for agriculture, the length of growing seasons and yield potential, particularly along the margins of semi-arid and arid areas, are expected to decrease [6]. This would further adversely affect food security and exacerbate malnutrition in the continent. Rural farmers, whose livelihoods depend on the use of natural resources, are likely to bear the effect of adverse impacts of climate change [7]. Climate change poses a great threat to human security through erratic rainfall patterns and decreasing crop yields, contributing to increased hunger. Further, adverse climate change impacts on natural systems and resources, infrastructure and labour productivity may lead to reduced economic growth exacerbating poverty [8]. This is because the agricultural sector is a critical mainstay of local livelihoods and the contribution of agriculture to GDP is significant. On average about $43 \%$ of the national GDP of developing countries is generated by agriculture and related activities [9]. Moreover, developing countries whose economies depend on the agricultural sector are critically vulnerable because agricultural production by its nature is highly dependent on annual weather conditions and natural resources. Due to its geographical location and also because of its least adaptive capacities, Eritrea is one of the most vulnerable countries of the world to the adverse effects of climate change. Agricultural production, which is the main economic stay of the country, was, for example, severely affected in the past due to the changing and unpredictable patterns of precipitation [10].

Many studies have assessed the vulnerability of countries, regions, and population groups to the adverse impacts of climate change in order to identify priorities for action. Few if any have critically assessed vulnerability at the individual household level [11]. Although studies conducted on an aggregation of the communities as a whole can give an important clue on the overall vulnerability of a country, region or population group, it undermines the individual vulnerability that each household faces in the given community. The assessment of vulnerability and adaptation to climate change at the farming household level in developing countries focused on Eritrea is, therefore, the main theme of this study.

\section{Methodology}

\subsection{Description of the Study Area}

The study area was conducted in different agro-ecological zones of Eritrea including the high land planes, the midlands and the western and eastern lowlands. Eritrea is located in the northern part of the Horn of Africa, sharing a border with Sudan, Ethiopia and Djibouti with a landmass area of, about $125,700 \mathrm{~km}^{2}$ including the islands, and a coastline covering some 1,720 kilometres [12]. Cropping and farming systems differ according to agroecological differences. Whereas the households in the high land planes practices mixed farming of cereal crops, pulses and oil crops, in the western, eastern lowlands and the midlands practice more of pastoralism with little crop farming. Livestock production constitutes an important part of the agricultural activities of the country [13]. 


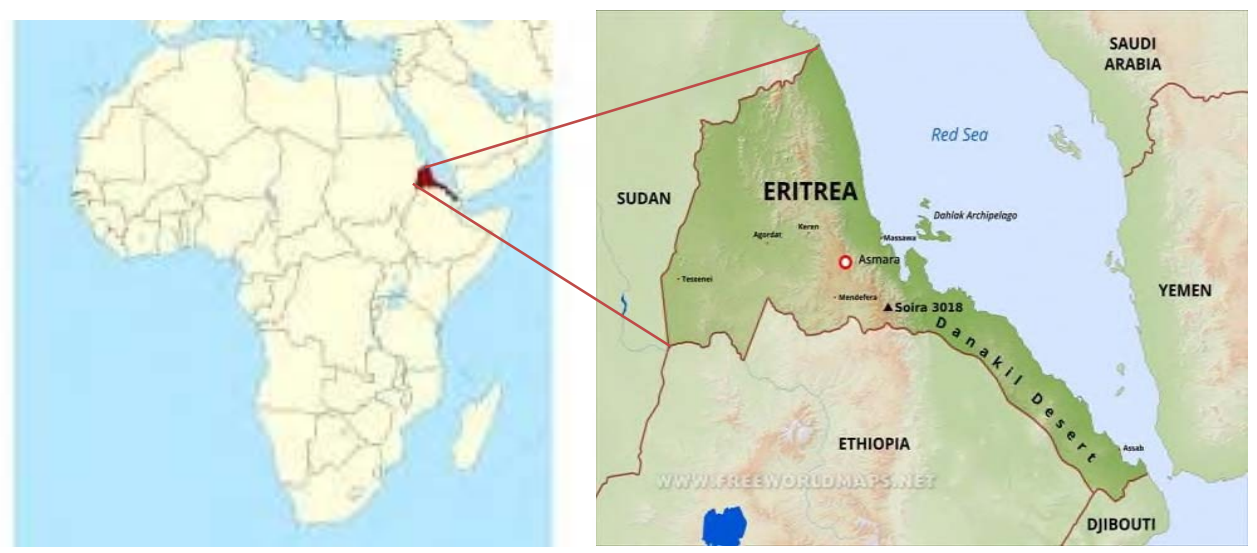

Fig. 1. Physical map of Eritrea and its location in Africa, Source: Google.com. Visited April 2020.

\subsection{Methods of data collection and analysis}

A household-level cross-sectional data from the 'Baseline Survey of Agricultural Households' conducted in 2016 by the Ministry of Agriculture, Eritrea was used for the analysis. This dataset provides information on demographic and socio-economic characteristics and indicators to vulnerability, resilience and coping mechanisms. Moreover, secondary data was also collected from relevant offices and documents to support the primary data. Focus groups discussion on key informant (men, women and youth groups), were also conducted using the Participatory Rural Appraisal (PRA) method. More data on climate variability and natural disasters were obtained from Google website. For this purpose, unstructured questionnaires were prepared. 656 data collection was collected with trained enumerators who could speak the local language.

Livelihood Vulnerability Index (LVI) was used as the main tool to calculate and determine the level of vulnerabilities of farming households to climate change. Descriptive statistics including mean standard deviation were also used in the analysis.

\subsection{Approaches to Vulnerability Analysis}

Vulnerability analysis involves various approaches including the socioeconomic, the biophysical and the integrated assessment approaches [14]. Socioeconomic vulnerability assessment approach focuses on the socioeconomic and political status of individuals or social groups. The fact that individuals differ in socioeconomic factors, the vulnerability level and resilience among each household become quite variable. Socioeconomic factors such as gender, level of education, household size, access to credit, wealth, health status, access to information and technology, social capital, political power, and so on, are responsible for the variations in vulnerability levels and resilience $[15,16]$. In this regard, vulnerability is constructed by society as a result of institutional and economic changes and is considered to be a starting point or a state that exists within a system before it encounters a hazard event. This explains that the socioeconomic approach focuses on identifying the adaptive capacity of individuals or communities based on their internal characteristics [17]. The socioeconomic approach tends to overlook the availability and impact of natural resource bases that potentially counteract the negative impacts of environmental shocks [18].

The biophysical approach attempts to assess the level of damage that a given environmental stress causes on both social and biological systems. It is sometimes known 
as an impact assessment. The emphasis is on the vulnerability or degradation of biophysical conditions [19]. It is a dominant approach employed in studies of vulnerability to natural hazards and climate change. Although the biophysical vulnerability approach is a necessary and important component of vulnerability, it is not a sufficient condition. Moreover, it does not take into account the human agency both in producing vulnerability and in coping or adapting to it. The approach overemphasizes extreme events while neglecting root causes and everyday social processes that influence differential vulnerability [17].

The integrated assessment approach somehow overcomes the limitations attributed to the socioeconomic or biophysical approaches taken separately. It has the synergic advantage resulted from combining the two approaches. Many researchers [18] and [16] preferred this approach, in the analysis of agro-ecological based vulnerability analysis and in the analysis of the regional-based vulnerability, respectively. This approach uses different datasets, ranging from socioeconomic datasets to biophysical factors. These datasets certainly have different yet unknown weights. It also fails to fully account the dynamism in vulnerability. Yet, it is a robust approach in terms of policy decisions [20].

The Livelihood Vulnerability Index (LVI) is an integrated approach used to analyse the vulnerability of farm households to climate change [21]. The LVI was originally designed to provide development organizations, policymakers and planners with a practical tool to understand contributions of demographic, social and physical factors to climate vulnerability [22]. This provides a flexible approach where development planners can refine and focus their analysis to suit the needs of each geographical location [23]. While researchers are flexible to add, according to a situation, relevant indicators to the components, the LVI is mainly comprised of seven major components: (i) sociodemographic profile (SDP), (ii) livelihood strategies (LS), (iii) social networks (SN), (iv) food $(\mathrm{F}),(\mathrm{v})$ health $(\mathrm{H})$, (vi) water $(\mathrm{W})$, and (vii) natural disasters and climate variability (NDCV) [24]. The possibility to be flexible in choosing indicators gives LVI some degree of subjectivity in the analysis [25]. Besides being simple to construct, the LVI measure has the advantage of being easy to understand. Moreover, this approach allows integrating the subcomponents into 3 dimensions: exposure, sensitivity, and adaptive capacity. The use of an equal-weighing scheme has been pointed out as an important limitation of this approach. Table 1 shows a list of the major components and sub-components including the unit of measurement and proposed functional relationship.

\subsubsection{Calculating the LVI}

While each major component is composed of a different number of sub-components each sub-component is made to contribute equally to the overall index. There is a need to standardize each component because each sub-component is measured on a different scale. In this respect, the LVI uses a balanced weighted average approach [26]. The equation used for this conversion was adapted from that used in the Human Development Index to calculate the life expectancy index. The ratio of the difference of the actual LVI values and a pre-selected minimum and the range of predetermined maximum and minimum is calculated as follows $[25,26]$ :

$$
\text { index }_{s d}=\frac{s_{d}-s_{\min }}{s_{\max }-s_{\min }}
$$

where $S d$ is the original sub-component for a household $d$, and $S_{\min }$ and $S_{\max }$ are the minimum and maximum values, respectively, for each sub-component determined using data from the households' characteristics. These minimum and maximum values are used to 
transform this indicator into a standardized index so that it could be integrated into the major component of the LVI. For variables that measure frequencies such as, for example, the 'per cent of households reporting where a $\mathrm{HH}$ has not attended school in their community,' the minimum value is set at 0 and the maximum at 100 . Some subcomponents such as the 'average agricultural livelihood diversity index' are created by taking the inverse of the crude indicator because an increase in the crude indicator, in this case, is assumed to decrease vulnerability. In other words, it is assumed that a household who farms and raises animals is less vulnerable than a household who only farms. By taking the inverse of the crude indicator, it is created a number that assigns higher values to households with a lower number of livelihood activities. The maximum and minimum values are also transformed following this logic and Eq. (1) used to standardize these subcomponents.

After each was standardized, the sub-components were averaged using Eq. (2) to calculate the value of each major component:

$$
M_{d}=\frac{\sum_{i=1}^{n} i_{\text {dex }} \text { sdi }}{n}
$$

where $M_{d}=$ one of the seven major components for HH $d$ [(SDP), (LS), (SN), (H), (F), (W), or (NDCV)]; index sdi represents the sub-components, indexed by $i$, that make up each major component, and $n$ is the number of sub-components in each major component.

Once values for each of the seven major components for a $\mathrm{HH}$ are calculated, they are averaged using Equation (3) to obtain the HH level of LVI:

$$
L V I_{d}=\frac{\sum_{i=1}^{7} w m_{i} M_{d}}{\sum_{i=1}^{7} w m_{i}}
$$

which can also be expressed as:

$$
L V I_{d}=\frac{w s d p S D P_{d}+w l s L S_{d}+w s n S N_{d}+w h H_{d}+w f F_{d}+w w W_{d}+w n d c v N D C V_{d}}{w s d p+w s l+w s n+w w+w n d c}
$$

where $L V I_{d}$, the Livelihood Vulnerability Index for $\mathrm{HH} d$, equals the weighted average of the seven major components. The weights of each major component, $w M_{i}$, are determined by the number of sub-components that make up each major component and are included to ensure that all sub-components contribute equally to the overall LVI [27]. In this case, the LVI is scaled from the lowest value (least vulnerable) to the highest value (most vulnerable).

Table 1. Livelihood Vulnerability Index (LVI) major components, sub-component, units and assumed functional relationship.

\begin{tabular}{|l|l|l|l|}
\hline $\begin{array}{l}\text { Major } \\
\text { component }\end{array}$ & Sub-component & Units & Assumed functional relationship \\
\hline & Dependency ratio & ratio & $\begin{array}{l}\text { The higher ratio reflects less } \\
\text { capacity to adapt }\end{array}$ \\
\hline
\end{tabular}




\begin{tabular}{|c|c|c|c|}
\hline \multirow{3}{*}{$\begin{array}{l}\text { Socio } \\
\text { demographic } \\
\text { profile } \\
\text { (SDP) }\end{array}$} & $\%$ of female-headed households & $\%$ & $\begin{array}{l}\text { Women typically have less } \\
\text { adaptive capacity }\end{array}$ \\
\hline & $\begin{array}{l}\text { Average age of female head of } \\
\text { household (Age) }\end{array}$ & $1 /$ years & $\begin{array}{l}\text { Ages and experience more } \\
\text { adaptive to climate change }\end{array}$ \\
\hline & $\begin{array}{l}\text { Per cent of households where } \mathrm{HH} \text { has } \\
\text { NOT attended school }\end{array}$ & $\%$ & $\begin{array}{l}\text { Education makes people more } \\
\text { aware and able to adjust to climate } \\
\text { change condition }\end{array}$ \\
\hline \multirow{4}{*}{$\begin{array}{l}\text { Livelihood } \\
\text { Strategies } \\
\text { (LS) }\end{array}$} & $\begin{array}{l}\% \text { of households dependent solely on } \\
\text { agriculture as a source of income } \\
\text { (Profession, mainstay) }\end{array}$ & $\%$ & $\begin{array}{lcc}\text { Low diversity } & \text { implies } & \text { low } \\
\text { adaptive capacity } & & \end{array}$ \\
\hline & $\begin{array}{l}\text { Average livestock diversification } \\
\text { index }\end{array}$ & average & $\begin{array}{l}\text { Diverse species of livestock } \\
\text { reduces the risk of major losses }\end{array}$ \\
\hline & $\begin{array}{l}\text { Average agricultural livelihood } \\
\text { (Income) diversity index } \\
\text { (scaled 1-5) }\end{array}$ & $\begin{array}{l}\text { 1/No of } \\
\text { livelihoods }\end{array}$ & $\begin{array}{l}\text { Low income diversity implies low } \\
\text { adaptive capacity. Income } \\
\text { diversification increases adaptive } \\
\text { capacity }\end{array}$ \\
\hline & $\begin{array}{l}\text { Poverty level (based on income) } \\
\text { (scaled 1-5) }\end{array}$ & $\begin{array}{l}\text { 1/income } \\
\text { diversity }\end{array}$ & $\begin{array}{l}\text { The poor have lower adaptive } \\
\text { capacity }\end{array}$ \\
\hline \multirow[t]{5}{*}{$\begin{array}{l}\text { Social } \\
\text { network } \\
(\mathrm{SN})\end{array}$} & $\begin{array}{l}\text { Average receive : give ratio } \\
\text { Expenditure : Income ratio }\end{array}$ & ratio & $\begin{array}{l}\text { High amount of receiving than } \\
\text { giving indicates stress, less } \\
\text { capacity to adapt }\end{array}$ \\
\hline & $\begin{array}{l}\text { Households not having extension } \\
\text { service (extension) }\end{array}$ & $\%$ & $\begin{array}{l}\text { Extension services strengthen } \\
\text { adaptive capacity }\end{array}$ \\
\hline & $\begin{array}{l}\text { Households not having access to } \\
\text { credit (credit) }\end{array}$ & $\%$ & $\begin{array}{l}\text { Credit services strengthen adaptive } \\
\text { capacity }\end{array}$ \\
\hline & $\begin{array}{l}\text { Households not having access to } \\
\text { market (market) }\end{array}$ & $\%$ & $\begin{array}{l}\text { Market services strengthen } \\
\text { adaptive capacity }\end{array}$ \\
\hline & $\begin{array}{l}\% \text { of households not associated with } \\
\text { any organization (cooperative/group) }\end{array}$ & $\%$ & $\begin{array}{l}\text { Cooperative services strengthen } \\
\text { adaptive capacity }\end{array}$ \\
\hline \multirow{6}{*}{$\begin{array}{l}\text { Food } \\
\text { (F) }\end{array}$} & $\begin{array}{l}\text { Average number of months } \\
\text { households } \\
\text { struggle to find food }\end{array}$ & $1 /$ months & $\begin{array}{l}\text { HH with fewer months of their } \\
\text { own food are more susceptible and } \\
\text { sensitive to the vulnerability }\end{array}$ \\
\hline & $\begin{array}{l}\% \text { of households that do not save } \\
\text { crops (feel food insecurity) }\end{array}$ & $\%$ & $\begin{array}{l}\text { Lower food security implies higher } \\
\text { sensitivity to disasters }\end{array}$ \\
\hline & $\begin{array}{l}\% \text { of households that do not save } \\
\text { seeds }\end{array}$ & $\%$ & $\begin{array}{l}\text { Lower saving level implies higher } \\
\text { sensitivity to disasters }\end{array}$ \\
\hline & $\begin{array}{l}\% \text { of households that do not produce } \\
\text { sufficient food }\end{array}$ & $\%$ & $\begin{array}{l}\text { Lower production level implies } \\
\text { higher sensitivity to disasters }\end{array}$ \\
\hline & $\begin{array}{l}\% \text { of households that depend on aid } \\
\text { for most of the times }\end{array}$ & $\%$ & $\begin{array}{l}\text { More depend on aid high } \\
\text { sensitivity }\end{array}$ \\
\hline & Number of meals per day & $1 /$ number & $\begin{array}{l}\text { Less number of meals high } \\
\text { sensitivity }\end{array}$ \\
\hline \multirow{5}{*}{$\begin{array}{l}\text { Health } \\
\text { (H) }\end{array}$} & $\begin{array}{l}\% \text { of households with no access to a } \\
\text { health facility }\end{array}$ & $\%$ & Low access high sensitivity \\
\hline & $\begin{array}{l}\text { Average time to health facility } \\
\text { (distance) }\end{array}$ & minutes & $\begin{array}{l}\text { The more they travel the more } \\
\text { sensitive }\end{array}$ \\
\hline & $\begin{array}{l}\% \text { of households with no access to vet } \\
\text { clinic }\end{array}$ & $\%$ & Low access high sensitivity \\
\hline & Average time to vet clinic (distance) & minutes & $\begin{array}{l}\text { The more they travel the more } \\
\text { sensitive }\end{array}$ \\
\hline & $\begin{array}{l}\text { \% of households without access to } \\
\text { toilet }\end{array}$ & $\%$ & Low access high sensitivity \\
\hline Water & $\begin{array}{l}\% \text { of household reported having water } \\
\text { availability problem (access to public } \\
\text { tap) }\end{array}$ & $\%$ & Low access high sensitivity \\
\hline
\end{tabular}




\begin{tabular}{|c|c|c|c|}
\hline \multirow[t]{5}{*}{$(\mathrm{W})$} & $\begin{array}{l}\% \text { of households that utilize a natural } \\
\text { water source }\end{array}$ & $\%$ & $\begin{array}{l}\text { More dependent on natural water } \\
\text { source with less sanitation more } \\
\text { sensitive }\end{array}$ \\
\hline & $\begin{array}{l}\% \text { of households that do not have a } \\
\text { consistent water supply (availability of } \\
\text { tap in residence) }\end{array}$ & $\%$ & Low supply high sensitivity \\
\hline & $\begin{array}{l}\% \text { of households that have access to } \\
\text { the dam }\end{array}$ & $\%$ & $\begin{array}{l}\text { HH with more access to dam are } \\
\text { benefited than others }\end{array}$ \\
\hline & $\begin{array}{l}\% \text { of households who use unprotected } \\
\text { well water }\end{array}$ & $\%$ & $\begin{array}{l}\text { Less sanitation of water more } \\
\text { sensitive }\end{array}$ \\
\hline & $\begin{array}{l}\% \text { of households who use protected } \\
\text { public well }\end{array}$ & $\%$ & $\begin{array}{l}\text { More protected more sanitation } \\
\text { less sensitive }\end{array}$ \\
\hline \multirow[t]{3}{*}{$\begin{array}{l}\text { Natural } \\
\text { disasters and }\end{array}$} & $\begin{array}{l}\text { Average Number of Flood and } \\
\text { Drought over the past } 5 \text { years }\end{array}$ & average & $\begin{array}{l}\text { More disaster means more } \\
\text { vulnerable }\end{array}$ \\
\hline & $\begin{array}{l}\% \text { of Households that did not receive } \\
\text { any warning about the upcoming } \\
\text { Natural Disaster }\end{array}$ & $\%$ & $\begin{array}{l}\text { The more the warning received the } \\
\text { less vulnerable }\end{array}$ \\
\hline & $\begin{array}{l}\% \text { of Households with an injury or } \\
\text { death as a result of natural disasters }\end{array}$ & $\%$ & $\begin{array}{l}\text { The more injured the more } \\
\text { vulnerable }\end{array}$ \\
\hline \multirow{6}{*}{$\begin{array}{l}\text { climate } \\
\text { variability } \\
(\mathrm{NDCV})\end{array}$} & $\begin{array}{l}\text { Maximum (monthly) temperature } \\
(2001-2010)\end{array}$ & $\left(\mathrm{T}^{0} \mathrm{C}\right)$ & $\begin{array}{l}\text { The higher the variability the more } \\
\text { vulnerable }\end{array}$ \\
\hline & $\begin{array}{l}\text { Minimum (Monthly) temperature } \\
(2001-2010)\end{array}$ & $\left(\mathrm{T}^{0} \mathrm{C}\right)$ & $\begin{array}{l}\text { The higher the variability the more } \\
\text { vulnerable }\end{array}$ \\
\hline & $\begin{array}{l}\text { Mean monthly temperature (1991- } \\
\text { 2016) }\end{array}$ & $\left(\mathrm{T}^{0} \mathrm{C}\right)$ & $\begin{array}{l}\text { The higher the variability the more } \\
\text { vulnerable }\end{array}$ \\
\hline & $\begin{array}{l}\text { Mean (SD) of the monthly average of } \\
\text { average Temperature }(1991-2016)\end{array}$ & $\left(\mathrm{T}^{0} \mathrm{C}\right)$ & $\begin{array}{l}\text { The higher the variability the more } \\
\text { vulnerable }\end{array}$ \\
\hline & $\begin{array}{l}\text { Mean SD of monthly average } \\
\text { precipitation (from 1991- } 2016\end{array}$ & $\begin{array}{l}\text { millimetre } \\
(\mathrm{mm})\end{array}$ & $\begin{array}{l}\text { The higher the variability the more } \\
\text { vulnerable }\end{array}$ \\
\hline & $\begin{array}{l}\text { Mean monthly Precipitation (1991- } \\
\text { 1916) }\end{array}$ & $\begin{array}{l}\text { millimetre } \\
(\mathrm{mm})\end{array}$ & $\begin{array}{l}\text { The higher the variability the more } \\
\text { vulnerable }\end{array}$ \\
\hline
\end{tabular}

\subsubsection{Calculating the LVI-IPCC: IPCC framework approach}

The LVI components reflect the IPCC (2001) vulnerability concept in terms of exposure, adaptive capacity and sensitivity. It uses multiple indicators to assess exposure to natural disasters in the short run like flooding and hailstorm and long terms like drought hazards, and climate variability, including temperature and precipitation variability. The social and economic characteristics of households affect their adaptive capacity, and current health, food, and water resource characteristics that determine their sensitivity to climate change impacts. The IPCC framework formula is given as follows [24]:

$$
C F_{d}=\frac{\sum w m_{i} M_{d i}}{\sum w m_{i}}
$$

where $C F_{d}$ is an IPCC- defined contributing factor (exposure, sensitivity, or adaptive capacity) for a $\mathrm{HH} d, M d i$ are the major components for $\mathrm{HH} d$ indexed by $i, w m_{i}$ is the weight of each major component, and $n$ is the number of major components in each contributing factor. Once exposure, sensitivity, and adaptive capacity were calculated, the three contributing factors will be combined using the following equation [14]: 


$$
L V I_{-} I P C C_{d}=\left(e_{d}-a_{d}\right) * s_{d}
$$

where $L V I-I P C C_{d}$ is the $L V I$ for $\mathrm{HH} d$ expressed using the IPCC vulnerability framework, $e$ is the calculated exposure score for $\mathrm{HH} d$ (equivalent NDCV major component), $a$ is the calculated adaptive capacity score for $\mathrm{HH} d$ (weighted average of the SD, LS, and SN major components), and $s$ is the calculated sensitivity score for $\mathrm{HH} d$ (weighted average of the $\mathrm{H}, \mathrm{F}$, and $\mathrm{W}$ major components), the lowest score being the least vulnerable and vice versa.

\section{Results and Discussion}

\subsection{Vulnerabilities in aggregate}

Table 3 depicts the values of VLI, of the major components and sub-components for the households, the lower value being the less vulnerable and vice versa. The major components are further aggregated into three vulnerability concept- the exposure, adaptive capacity and sensitivity (Table 2). The result of each of these is further discussed as follows. The VLI values are relative values to be compared among them.

Table 2. Categorization of major components into contributing factors of IPCC vulnerability.

\begin{tabular}{|l|l|}
\hline \multicolumn{2}{|c|}{ IPCC contributing factors to vulnerability Major components } \\
\hline Exposure & -Natural disasters and climate variability \\
\hline Adaptive capacity & -Socio-demographic profile \\
& -Livelihood strategies \\
& -Social networks \\
\hline Sensitivity & -Health \\
& - Food \\
& -Water \\
\hline
\end{tabular}

Exposure: The exposure component comprises of external factors such as climate variability and natural disaster. The variability in the mean monthly temperature (from 1991-2016), maximum and minimum monthly temperatures (from 2001- 2010), mean standard deviation (SD) of the monthly average of average temperature (from 1991-2016), mean SD of monthly average precipitation (from 1991-2016), and mean monthly precipitation (from1991-1916) were considered to evaluate the climate variability. 


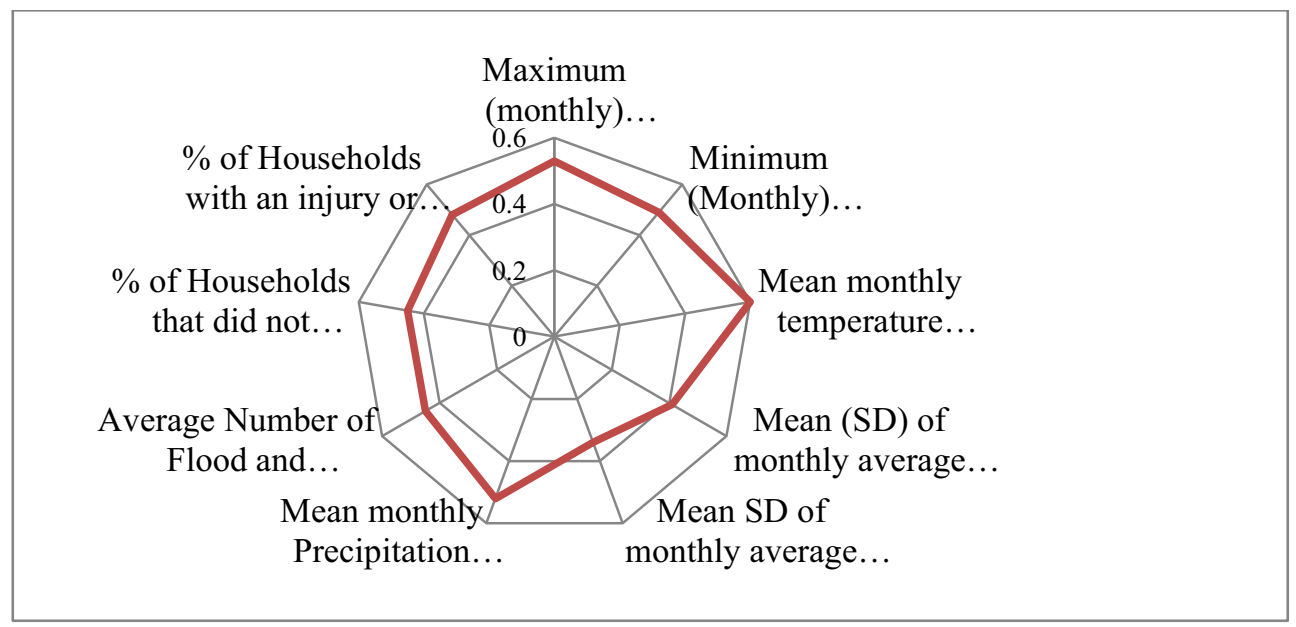

Fig. 2. Climate Vulnerability Index in terms of temperature and precipitation variation.

Almost all the exposure indicators considered here scored high values suggesting a higher degree of vulnerability of the households to climate change. The high variability in precipitation and temperature during the given period of time resulted in high vulnerability score and, hence, a high degree of exposure (0.2973). A higher exposure, in turn, contributed to a higher vulnerability to the concerned farming household (Figure 2).

Adaptive capacity: The adaptive capacity is composed of three major components namely the social network, livelihood strategies and socio-demographic profile. The social network was composed of five sub-components including expenditure-income ratio, percentage of households not having access to extension service, percentage of households not having access to credit, percentage of households not having access to market, and percentage of households not having access to social institutions (cooperatives). The expenditure-income ratio was high (0.697) indicating that the majority of the households spent more than they could earn income. About three quarters $(74.0 \%)$ of the expenses were spent on basic consumer goods such as the purchase of grain food, sugar, salt, kerosene etc. On the other hand, the expenditure on human capital such as health and education was limited to $9.0 \%$ only. The poor spent much of their income on purchases of food and other basic consumer goods that contributed to higher vulnerability. Since much of the income of the households was directed towards the fulfilment of daily needs, it was less likely to invest in a long term human development. Moreover, the households' weak access to extension services, access to credit and market contributed to the vulnerable social network. Therefore, the high score in a vulnerable social network $(0.251885)$ contributed to low adaptive capacity to households (Figure 3). 


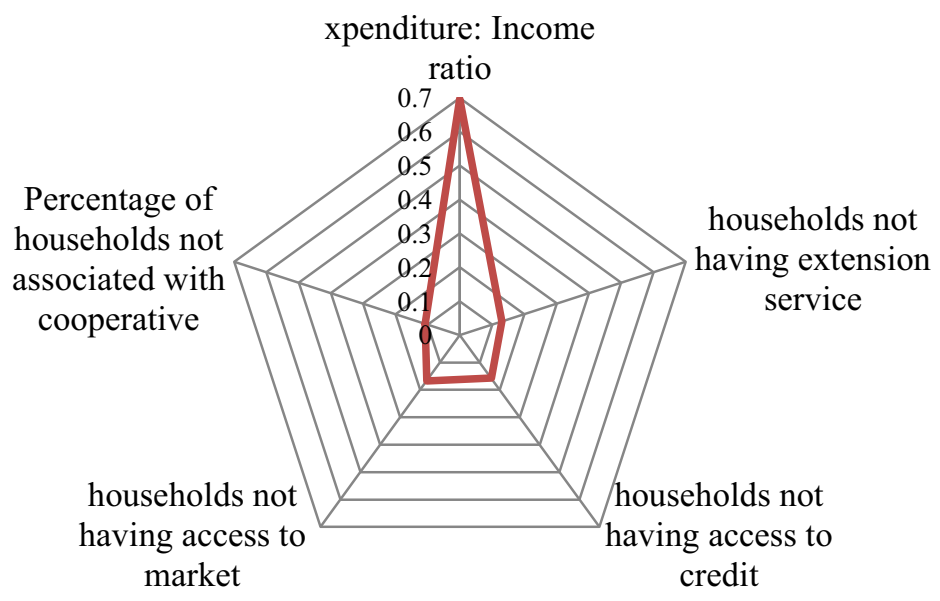

Fig. 3. Contribution of the social network to the adaptive capacity

The second major component of the adaptive capacity was the livelihood strategies of the households. Four sub-components including per cent of households dependent solely on agriculture as a source of income (mainstay), average livestock diversification index (livestock index), income diversity index, and poverty level (based on income) were considered to evaluate the livelihood strategies. The vulnerability indicators selected for the analyses of the income diversity index and poverty index were scaled from 1 to 5 a higher score indicating a lower adaptive capacity. Accordingly, the income diversity index and poverty index indicated that the households had a poor livelihood strategy to develop an adaptive capacity.

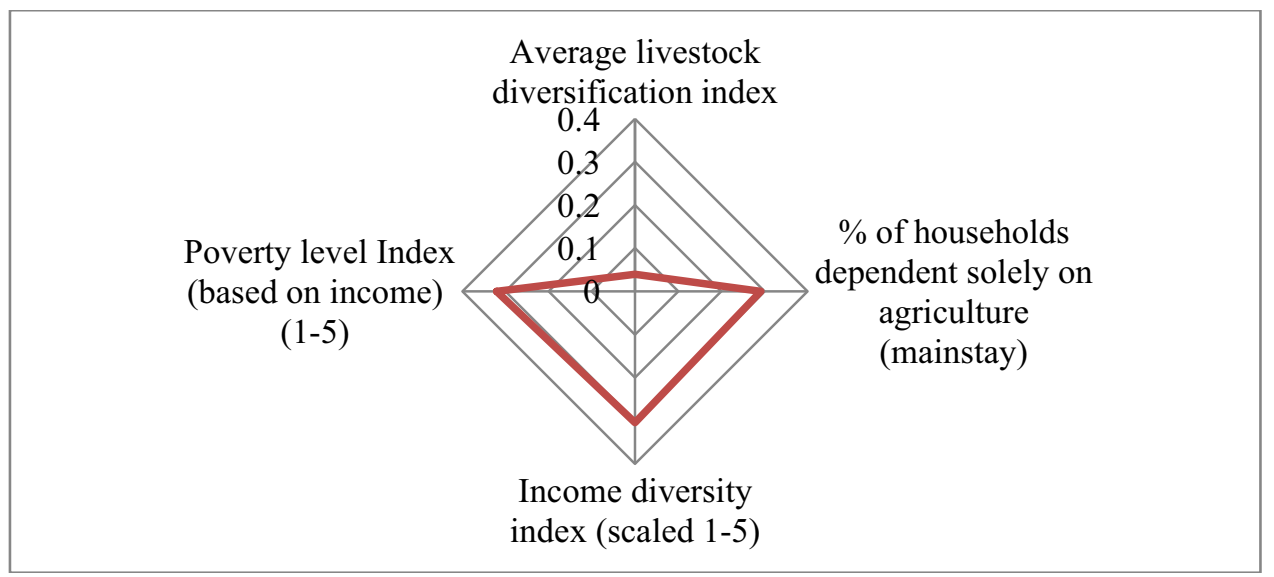

Fig. 4 Contribution of the livelihood strategy component to adaptive capacity

In terms of the farmers' mainstay, $39 \%, 6 \%$ and $55 \%$ of the respondent households considered themselves as pastoralists, agro-pastoralists and crop farmers, respectively. The low percentage of agro-pastoralists (a mainstay that combines pastoralists and crop farming) indicated that the diversity level in terms of the farmers' mainstay was low. Low 
diversity, in turn, implies low adaptive capacity. An average index was taken to calculate the livestock diversity index based on the conversion factors expressed in tropical livestock units [27]. Given the diverse types of animals that the households keep, their livelihood strategy in terms of livestock index was relatively better than other strategies. The overall score of the livelihood strategy component was found to be $(0.239184)$ contributing to low adaptive capacity (Figure 4).

Table 3. Values of LVI, Major Components and sub-components

\begin{tabular}{|c|c|c|c|c|c|}
\hline Sub-component & Units & Index & \multicolumn{2}{|c|}{ Major component } & $L V I$ \\
\hline Dependency ration & ratio & 0.7300 & \multirow{4}{*}{$\begin{array}{l}\text { Socio } \\
\text { demographic } \\
\text { profile }\end{array}$} & \multirow{4}{*}{0.2285} & \multirow{13}{*}{$\begin{array}{l}\text { Adaptive } \\
\text { capacity }\end{array}$} \\
\hline$\%$ of female-headed households & $\%$ & 0.4670 & & & \\
\hline $\begin{array}{l}\text { Average age of female head of } \\
\text { household }\end{array}$ & $1 /$ years & 0.1190 & & & \\
\hline $\begin{array}{l}\text { Per cent of households where } \\
\text { HH has NOT attended school }\end{array}$ & $\%$ & 0.1865 & & & \\
\hline $\begin{array}{l}\% \text { of households dependent } \\
\text { solely on agriculture as a source } \\
\text { of income }\end{array}$ & $\%$ & 0.2922 & \multirow{4}{*}{$\begin{array}{l}\text { Livelihood } \\
\text { Strategies } \\
\text { (a) }\end{array}$} & \multirow{4}{*}{0.2392} & \\
\hline $\begin{array}{l}\text { Average livestock diversification } \\
\text { index } \\
\text { (livestock index) }\end{array}$ & average & 0.0397 & & & \\
\hline $\begin{array}{l}\text { Average agricultural livelihood } \\
\text { (Income) diversity index (scaled } \\
1-5 \text { ) }\end{array}$ & $\begin{array}{l}1 / \# \\
\text { livelihoods }\end{array}$ & 0.3041 & & & \\
\hline $\begin{array}{l}\text { (poverty level based on income) } \\
\text { (scaled 1-5) }\end{array}$ & $\begin{array}{l}\text { 1/income } \\
\text { diversity }\end{array}$ & 0.320833 & & & \\
\hline $\begin{array}{l}\text { Average receive:give ratio } \\
\text { Expenditure : Income ratio }\end{array}$ & ratio & 0.6974 & \multirow{5}{*}{$\begin{array}{l}\text { Social network } \\
\text { (a) }\end{array}$} & \multirow{5}{*}{0.2519} & \\
\hline $\begin{array}{l}\text { households not having extension } \\
\text { service (extension) }\end{array}$ & $\%$ & 0.1297 & & & \\
\hline $\begin{array}{l}\text { households not having access to } \\
\text { credit (credit) }\end{array}$ & $\%$ & 0.1573 & & & \\
\hline $\begin{array}{l}\text { households not having access to } \\
\text { market (market) }\end{array}$ & $\%$ & 0.1669 & & & \\
\hline $\begin{array}{l}\% \text { of households not associated } \\
\text { with any organization } \\
\text { (cooperative/group) }\end{array}$ & $\%$ & 0.1081 & & & \\
\hline $\begin{array}{l}\text { Average number of months } \\
\text { households } \\
\text { struggle to find food }\end{array}$ & $1 /$ months & 0.2608 & \multirow{6}{*}{$\begin{array}{l}\text { Food } \\
(s)\end{array}$} & \multirow{6}{*}{0.1913} & \multirow{11}{*}{$\begin{array}{l}\text { Sensitivit } \\
\mathrm{y} \\
0.0984\end{array}$} \\
\hline $\begin{array}{l}\% \text { of households that do not } \\
\text { produce sufficient food }\end{array}$ & $\%$ & 0.1666 & & & \\
\hline $\begin{array}{l}\% \text { of households that do not save } \\
\text { crops (feel food insecurity) }\end{array}$ & $\%$ & 0.1387 & & & \\
\hline $\begin{array}{l}\% \text { of households that get less } \\
\text { than three meals per day }\end{array}$ & $\%$ & 0.3250 & & & \\
\hline $\begin{array}{l}\% \text { of households that depend on } \\
\text { aid for most of the times }\end{array}$ & $\%$ & 0.1120 & & & \\
\hline $\begin{array}{l}\% \text { of households that do not } \\
\text { save seeds }\end{array}$ & $\%$ & 0.1448 & & & \\
\hline $\begin{array}{l}\% \text { of households with no access } \\
\text { to health facility }\end{array}$ & $\%$ & 0.1842 & \multirow{5}{*}{ Health } & \multirow{5}{*}{0.2144} & \\
\hline $\begin{array}{l}\text { Average time to health facility } \\
\text { (distance) }\end{array}$ & minutes & 0.3230 & & & \\
\hline $\begin{array}{l}\% \text { of households with access to } \\
\text { vet clinic }\end{array}$ & $\%$ & 0.1741 & & & \\
\hline $\begin{array}{l}\text { Average time to vet clinic } \\
\text { (distance) }\end{array}$ & minutes & 0.2600 & & & \\
\hline$\%$ of households without access & $\%$ & 0.1305 & & & \\
\hline
\end{tabular}




\begin{tabular}{|c|c|c|c|c|c|}
\hline to toiles & & & & & \multirow{16}{*}{$\begin{array}{l}\text { Exposure } \\
0.2969\end{array}$} \\
\hline $\begin{array}{l}\% \text { of household reported to have } \\
\text { water availability problem } \\
\text { (access to public tap) }\end{array}$ & $\%$ & 0.1491 & \multirow[t]{6}{*}{ Water } & \multirow{6}{*}{0.1305} & \\
\hline $\begin{array}{l}\% \text { of households who use } \\
\text { protected public well }\end{array}$ & $\%$ & 0.1201 & & & \\
\hline $\begin{array}{l}\% \text { of households that do not have } \\
\text { a consistent water supply } \\
\text { (availability of tap in residence) }\end{array}$ & $\%$ & 0.1047 & & & \\
\hline $\begin{array}{l}\% \text { of households who use } \\
\text { unprotected private well water }\end{array}$ & $\%$ & 0.1796 & & & \\
\hline $\begin{array}{l}\% \text { of households that utilize a } \\
\text { natural water source }\end{array}$ & $\%$ & 0.1229 & & & \\
\hline $\begin{array}{l}\% \text { of households that depend on } \\
\text { micro dam water }\end{array}$ & $\%$ & 0.1067 & & & \\
\hline $\begin{array}{l}\text { Average Number of Flood and } \\
\text { Drought over the past } 5 \text { years }\end{array}$ & average & 0.4502 & \multirow{3}{*}{$\begin{array}{l}\text { Natural } \\
\text { disasters } \\
\text { (e) }\end{array}$} & \multirow{3}{*}{0.4600} & \\
\hline $\begin{array}{l}\% \text { of Households that did not } \\
\text { receive any warning about } \\
\text { upcoming Natural Disaster }\end{array}$ & $\%$ & 0.4500 & & & \\
\hline $\begin{array}{l}\% \text { of Households with an injury } \\
\text { or death as a result of natural } \\
\text { disasters }\end{array}$ & $\%$ & 0.4803 & & & \\
\hline $\begin{array}{l}\text { Maximum (monthly) } \\
\text { temperature (2001- 2010) }\end{array}$ & $\left(\mathrm{T}^{0} \mathrm{C}\right)$ & 0.5300 & \multirow{6}{*}{$\begin{array}{l}\text { climate } \\
\text { variability }\end{array}$} & \multirow{6}{*}{0.2959} & \\
\hline $\begin{array}{l}\text { Minimum (Monthly) } \\
\text { temperature (2001 - 2010) }\end{array}$ & $\left(\mathrm{T}^{0} \mathrm{C}\right)$ & 0.4911 & & & \\
\hline $\begin{array}{l}\text { Mean monthly temperature } \\
(1991-2016)\end{array}$ & $\left(\mathrm{T}^{0} \mathrm{C}\right)$ & 0.6001 & & & \\
\hline $\begin{array}{l}\text { Mean (SD) of monthly average } \\
\text { of average Temperature (1991- } \\
2016)\end{array}$ & $\left(\mathrm{T}^{0} \mathrm{C}\right)$ & 0.4110 & & & \\
\hline $\begin{array}{l}\text { Mean SD of monthly average } \\
\text { precipitation (from 1991- } 2016\end{array}$ & $(\mathrm{~mm})$ & 0.3401 & & & \\
\hline $\begin{array}{l}\text { Mean monthly Precipitation } \\
(1991-1916)\end{array}$ & $(\mathrm{mm})$ & 0.5200 & & & \\
\hline
\end{tabular}

The Socio-demographic profile was the third major component of the adaptive capacity with a score of (0.209). Four sub-components were considered to analyse the sociodemographic profile, including dependency ratio, per cent of female-headed households, the average age of female-headed households, and per cent of households where no access to education. The average dependency ratio was 0.73 indicating that on average a large number of the $\mathrm{HH}$ members were dependent on the active members. This had an impact on the adaptive capacity of the HHs resulting in higher vulnerability. A higher dependency ratio is likely to reduce productivity growth. Growth in the non-productive population will diminish productive capacity and could lead to a lower long-run trend rate of economic growth. Family members at the age of 16 and below and above 65 were regarded as dependents. Female-headed households, as they had to play the role of both genders, had low adaptive capacity and hence vulnerable livelihood. More than $34 \%$ of the respondents did not have formal education which made them less adaptive and more vulnerable (figure 5). Education makes people more aware and able to adjust to change in the environmental condition. 


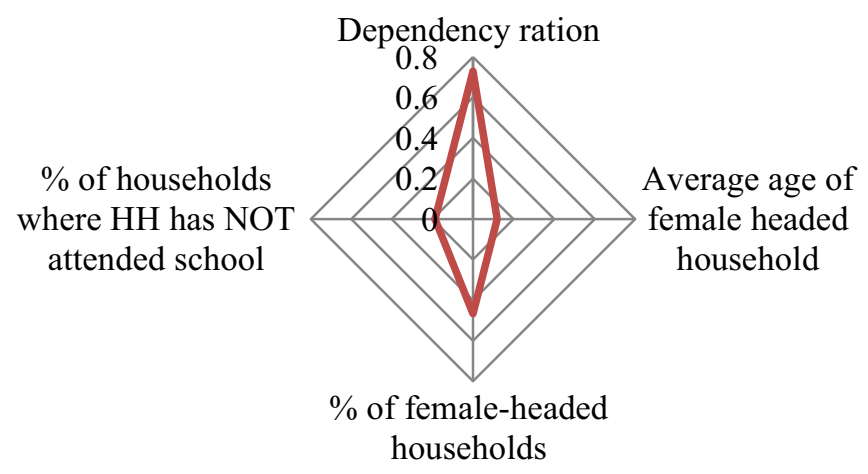

Fig. 5. Contribution of the Socio demographic profile to the adaptive capacity

Sensitivity: The sensitivity category of vulnerability is composed of three major components consisting of health, food and water. The health sensitivity component scored the highest (0.214) out of the three major components indicating that public health was a critical issue for both humans and their livestock. Five sub-components were considered in the health component including the percentage of households with no access to the health facility, average time to travel to the health facility in minutes, per cent of households with no access to the veterinary clinic, an average time to travel to the veterinary clinic in minutes, and per cent of households without access to toilets. There were a moderate to high variability of the public health factors that contributed to the health sensitivity of the households. About $70 \%$ of the respondents did not have access to toilet, $15 \%$ did not have any access to health facility clinics, and $48 \%$ had to travel more than an hour to get health services which made them sensitive and vulnerable (Figure 6).

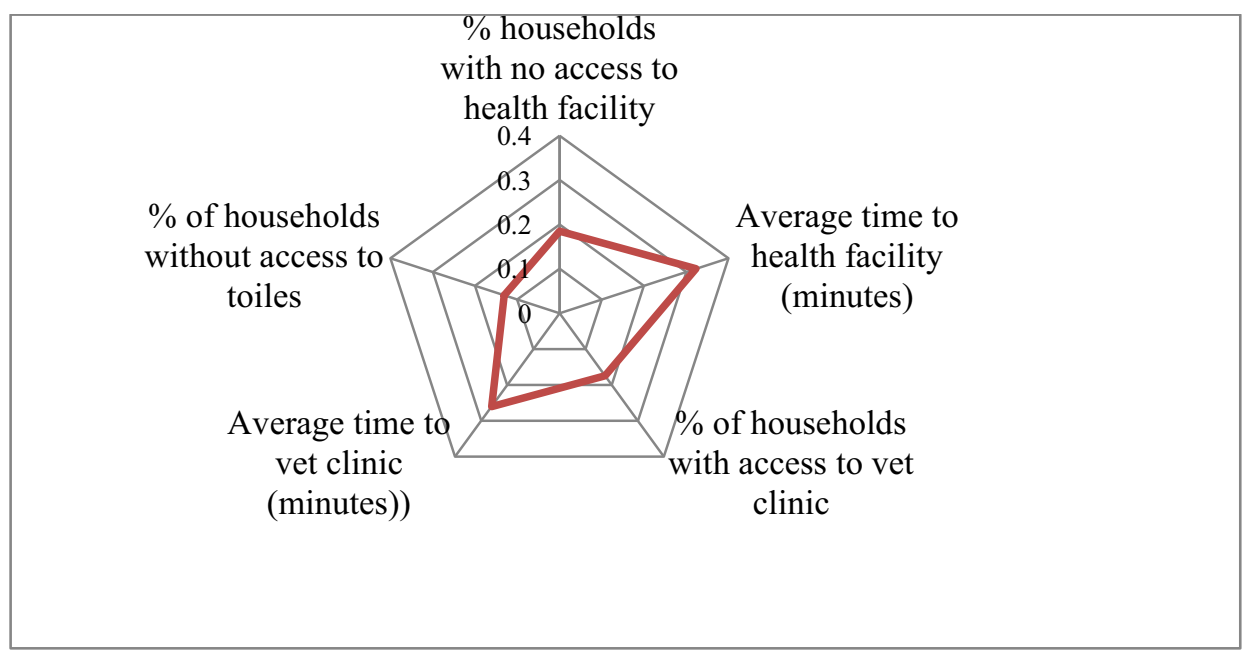

Fig. 6. Contribution of deficiency of public health to the sensitivity of households

Food is one of the major components that contribute to the sensitivity of the LVI. It is composed of six sub-components namely, an average number of months households struggle to find food, per cent of HHs that do not produce sufficient food, per cent of HHs that do not save crops (feel food insecurity) for future use, per cent of HHs that do not get three meals per day, per cent of HHs that depend on aid for most of the times, and per cent 
of HHs that do not save seeds. The result showed that the number of households that did not get three meals per day and the number of months HHs struggled to get food scored the highest indicating the prevalence of poverty. The per cent of HHs that did not produce sufficient food and did not save crops also justify the food shortage that makes the households sensitive and vulnerable (Figure 7). Poverty brings about a negative impact in different sectors including health complications, economic productivity and social evils.

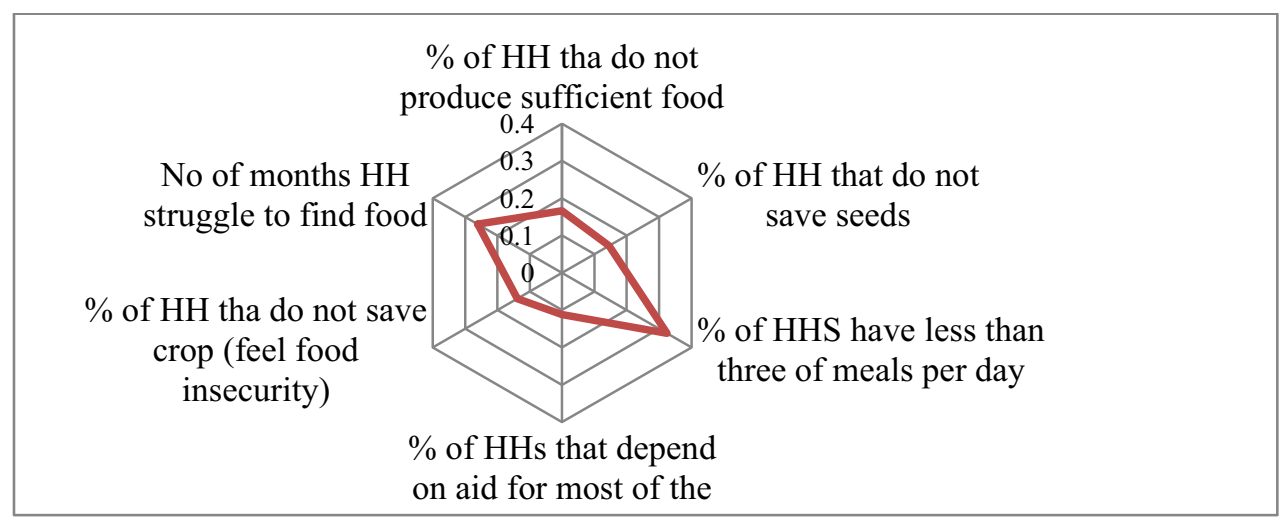

Fig. 7. Contribution of food sensitivity to the vulnerability of households

The third major component of Sensitivity was Water. Six sub-components including, percentage of households reported to have water shortage problem, percentage of households who use unprotected public well, percentage of households that do not have a consistent water supply, percentage of households who use unprotected private well water, percentage of households that utilize a natural water source, and percentage of households that depend on pond or dam water comprise the water component. The result showed that there were different precarious sources of water for domestic consumption including unprotected public and private wells, rivers, streams and ponds contributing to the sensitivity component of vulnerability (Figure 8).

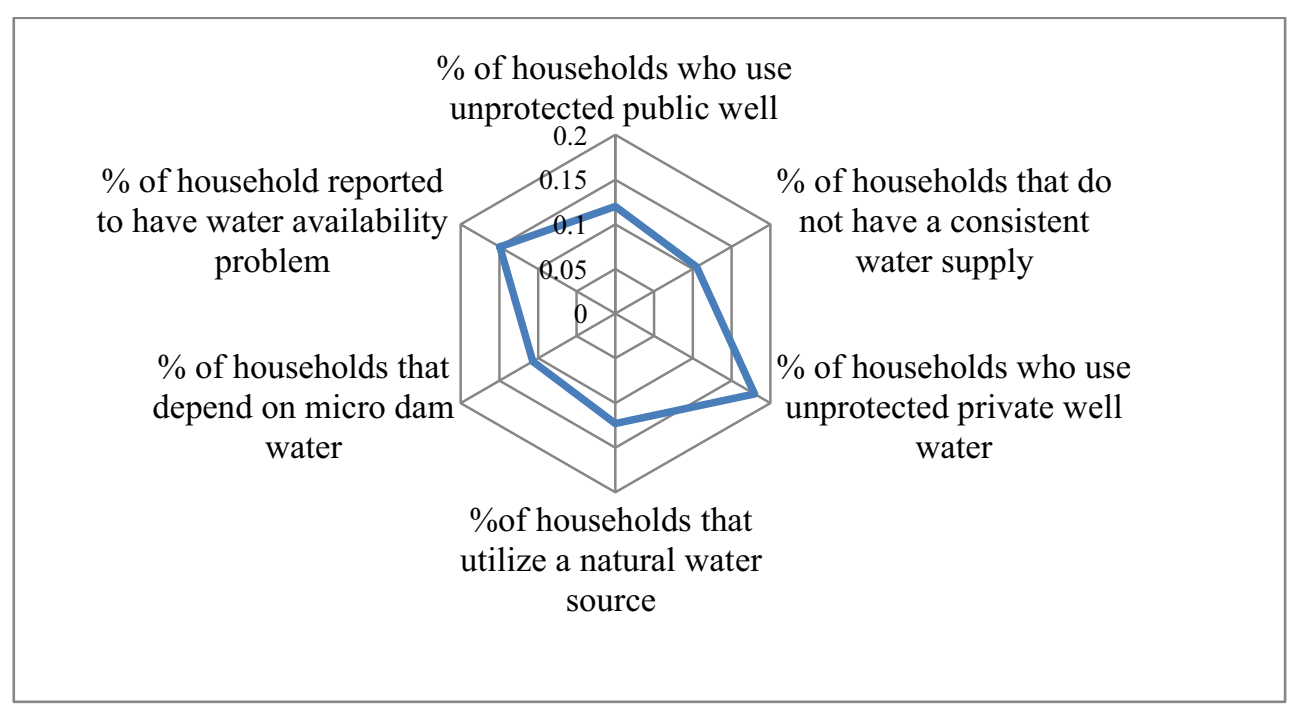

Fig. 8. Contribution of water sensitivity to the vulnerability of households

\subsubsection{The LVI_IPCC result of vulnerability}


The results of all the seven major components are summarized in (Figure 3.8). The vulnerability spider diagram ranges from $(0.131)$ water-related vulnerability component to (0.46) natural disaster component. The major components are further aggregated into three vulnerability components including exposure, sensitivity and adaptive capacity. The exposure of households to climate variability, in general, exceeds the sensitivity and adaptive capacity resulting in a high overall vulnerability to climate change. Natural disasters and Climate variability expressed in the form of exposure to drought, variation in temperatures and precipitation contribute most to the vulnerability component of the households. The impact of Socio-demographic profile, Livelihood Strategies, Social network, Food, Health and Water in the form of adaptive capacity and sensitivity contributed to the vulnerability of the households in descending order (Figure 9).

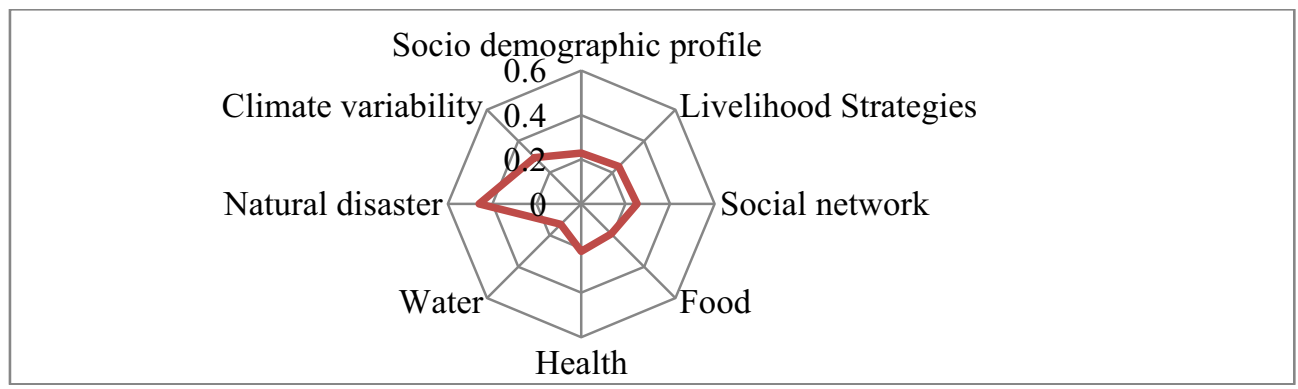

Fig. 9. Vulnerability spider diagram for the major components of the (LVI)

Following the LVI_IPCC analysis, a vulnerability triangle has been drawn from the major components by combining exposure, adaptive capacity and sensitivity. The exposure to natural disaster and climate variability of the households and their sensitivity to their internal situation like food, water and health overweigh their adaptive capacity in the form of a socio-demographic profile, livelihood strategies and social network (Figure 10).

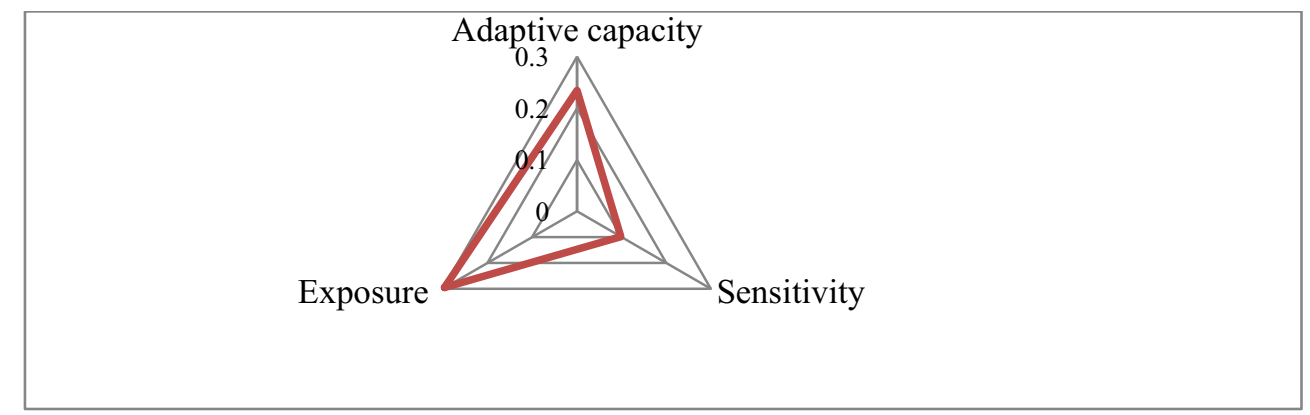

Fig. 10. LVI, exposure, sensitivity and adaptive capacity as combined from major vulnerability components

\section{2 Vulnerability levels of households}

Vulnerability level of households is analysed by applying the seven major vulnerability components at each household. The vulnerability level is scaled from least vulnerable with low vulnerability value to most vulnerable with the highest vulnerability value. Accordingly, only $12 \%$ of the respondents were found to be "less vulnerable" to climate change due to their strong adaptive capacity and low sensitivity. The rest $63 \%$ and $25 \%$ were vulnerable and highly vulnerable respectively (Figure 11). Households with a 
relatively lower level of education and particularly female headed households were found to be more vulnerable than otherwise. Households with no education or lower than primary level were $7.6 \%$ more vulnerable than households with higher level of education, and female-headed households were $25 \%$ more vulnerable than male-headed.

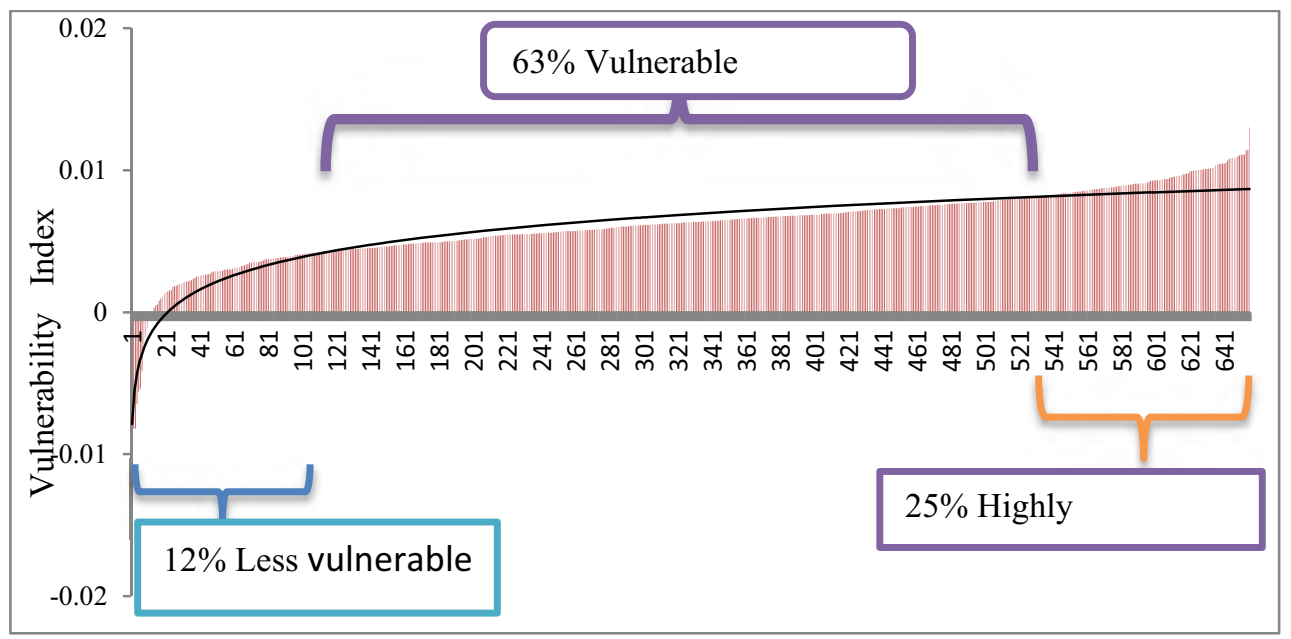

Fig. 11. HH's level of vulnerability from less to highly vulnerable

\section{Conclusion and Recommendation}

Vulnerability is described to be a function of three interrelated elements, exposure, sensitivity, and adaptive capacity. This implies that vulnerability of a household, society or community to environmental change depends not only on its exposure to the external factors like drought, and climate variability but also to its sensitivity and internal factors like short term coping mechanisms and long term adaptive capacity. Vulnerability assessments can play a vital role in the design of appropriate adaptation and mitigation policies targeted towards climate change and its impacts on farming households. Assessment of vulnerability in a particular individual, group, community, or household enables to have a clear and effective response to be formulated.

Climate change vulnerability is critical in Eritrea where the poor are the most at risk from the increased variability and volatility in weather patterns. One of the key climaterelated vulnerabilities of households in Eritrea is the dependence of their livelihoods mainly on rain-fed agriculture. The rain-fed agriculture-based livelihood in Eritrea aggravated by high variability in precipitation and temperature resulted in a high degree of exposure to climate change vulnerability. The vulnerability index analysis shows that an overall $88 \%$ of the farming households in Eritrea (25\% highly vulnerable and 63\% vulnerable) are regarded to be susceptible to climate change variability. This is mainly attributed to the high level of exposure and sensitivity and low level of adaptive capacity. Female-headed families and those belonging to disadvantaged social groups are more vulnerable and in need of being preferentially targeted by policy measures.

Development interventions by both government and/or development agents to mitigate vulnerability to climate change in developing countries including Eritrea could be done by targeting the exposure, sensitivity and adaptive capacity. Although, it may be difficult to deal directly with external factors, like drought, temperature and precipitation variability, an indirect action like the introduction of smart agriculture, and environmentally friendly livelihoods can have a substantial effect in the long run. Enhancing the livelihood 
strategies, social network and socio-demographic profile of the farming households can improve the adaptive capacity of farming households. Furthermore, by improving human resource development focusing on education, health, access to food, and water, households can develop resilience and reduce sensitivity.

\section{References}

1. M. Closset, S. Feindouno, P. Guillaumont, C. Simonet, "A Physical Vulnerability to Climate Change Index: Which are the most vulnerable developing countries?" Fond. pour les études Rech. sur le développement Int., 213, 1-53 (2018)

2. IPCC, "Summary for policymakers. In: Climate Change 2014: Impacts, Adaptation, and Vulnerability. Part A: Global and Sectoral Aspects. Contribution of Working Group II to the Fifth Assessment Report of the Intergovernmental Panel on Climate Change [Field, C.B.,]" Cambridge Univ. Press. Cambridge, United Kingdom New York, NY, USA, 1, 1-32 (2014)

3. D. McEntire, C. G. Crocker, E. Peters, "Addressing vulnerability through an integrated approach,” Int. J. Disaster Resil. Built Environ., 1(1), 50-64 (2010)

4. J. R. Hernández, "Society, Environment, Vulnerability, and Climate Change in Latin America,” Lat. Am. Perspect., 43(4), 29-42 (2016) doi: 10.1177/0094582X16641264

5. P. Alagidede, G. Adu, P. B. Frimpong, "The effect of climate change on economic growth: evidence from Sub-Saharan Africa," Environ. Econ. Policy Stud., 18(3), 417436 (2016) doi: 10.1007/s10018-015-0116-3

6. P. Reddy, Climate resilient agriculture for ensuring food security, 53(1) (2015)

7. M. Lackner, W. Chen, T. Suzuki, Handbook of Climate Change Mitigation and Adaptation (2016)

8. FAO, World Economic Situation and Prospects (2019)

9. P. Carmody, et al., New realities, new challenges : new opportunities for tomorrow' $s$ generation, 21(1) (2015)

10. R. T. Wilson, B. Partners, Z. Fre, "Agriculture in Eritrea : Roots of disaster and routes to development Agriculture in Eritrea :," (2018)

11. M. Debesai, "Rural household income diversification in developing countries: A Case study of Eritrea," E3S Web Conf., 175, 13014 (2020) doi: $10.1051 / \mathrm{e} 3 \operatorname{sconf} / 202017513014$

12. MLWE, "THE STATE OF ERITREA FOR THE GREAT GREEN WALL INITIATIVE (GGWI )," no. October 2012 (2015)

13. A. Jalloh, G. C. Nelson, T. S. Thomas, and H. Roy-macauley, East African Agriculture and Climate Change A Comprehensive Analysis, IFPRI (2013)

14. M. B. Hahn, A. M. Riederer, S. O. Foster, "The Livelihood Vulnerability Index : A pragmatic approach to assessing risks from climate variability and change - A case study in Mozambique," 19(1), 74-88 (2009) doi: 10.1016/J.GLOENVCHA.2008.11.002

15. M. Nelitz, S. Boardley, and R. Smith, "Tools for Climate Change Vulnerability Assessments for Watersheds," 125 (2013)

16. G. Tesso, "Individual level vulnerability to climate change impact among crop dependent communities of western Ethiopia,” Agric. Econ. Dev., 2, 356-370 (2013) 
17. G. Tesso, B. Emana, and M. Ketema, "Analysis of vulnerability and resilience to climate change induced shocks in North Shewa, Ethiopia," Agric. Sci., 3(6), 871-888 (2012) doi: 10.4236/as.2012.36106

18. T. T. Deressa, C. Ringler, R. M. Hassan, "Factors affecting the choices of coping strategies for climate extremes: The case of farmers in the Nile Basin of Ethiopia," IFPRI Discuss. Pap., 1032, 25 (2010)

19. B. I. A. Madu, "Spatial Vulnerability of Rural Households to Climate Change in Nigeria: Implications for Initial Security," Clim. Chang. African Polit. Stab., 3(4), 7998 (2012)

20. P. Copy, U. Proofs, Panel on Strategies and Methods for Climate-Related Decision Support Committee on the Human Dimensions of Global Change Division of Behavioral and Social Sciences and Education (2010)

21. D. T. Adu, J. K. M. Kuwornu, H. Anim-Somuah, N. Sasaki, “Application of livelihood vulnerability index in assessing smallholder maize farming households' vulnerability to climate change in Brong-Ahafo region of Ghana," Kasetsart J. Soc. Sci., 39(1), 2232 (2018)

22. J. Panthi, S. Aryal, P. Dahal, P. Bhandari, "Livelihood vulnerability approach to assessing climate change impacts on mixed agro-livestock smallholders around the Gandaki River Basin in Nepal," Reg. Environ. Chang., 16, 1121-1132 (2016) doi: 10.1007/s10113-015-0833-y

23. Ahsan, J. Warner, "The socioeconomic vulnerability index: A pragmatic approach for assessing climate change led risks-A case study in the south-western coastal Bangladesh," Elsevier, 8, 32-49 (2014) doi: 10.1016/j.ijdrr.2013.12.009

24. P. M. Etwire, "Application of Livelihood Vulnerability Index in Assessing Vulnerability to Climate Change and Variability in Northern Ghana Application of Livelihood Vulnerability Index in Assessing Vulnerability to Climate Change and Variability in Northern Ghana", Journal of Environment and Earth Science, 3(2) (2013)

25. J. Y. Gerlitz, M. Macchi, N. Brooks, R. Pandey, S. Banerjee, and S. K. Jha, "The Multidimensional Livelihood Vulnerability Index-an instrument to measure livelihood vulnerability to change in the Hindu Kush Himalayas," Clim. Dev., 9(2), 124-140 (2017)

26. C. Ludena, S. Yoon, "Local vulnerability indicators and adaptation to climate change: A survey. Inter-American Development Bank, Technical Note No. 857," no. Technical Note, 857, 51 (2015)

27. K. Van Der Geest, K. Warner, "Vulnerability, Coping and Loss and Damage from Climate Events," Hazards, Risks and Disasters in Societ, 121-144 (2015) doi: 10.1016/B978-0-12-396451-9.00008-1 